\title{
Crafting the Elastic Self? Gender and Identities in Senior Appointments in Irish Education
}

\author{
Dympna Devine*, Bernie Grummell and \\ Kathleen Lynch
}

This article considers the impact of new managerial reform on the recruitment and retention of women into senior management posts across the Irish education sector. In Ireland as elsewhere, the rhetoric of gender equality permeates new managerial reforms. Yet our data suggest that an emphasis on performativity and an intense commitment to paid work consolidates masculinist management cultures disguised through the ideology of choice. This works to the detriment of women, especially those with caring responsibilities. Drawing on studies of 23 top-level educational appointments in primary, secondary and higher education, we show how the relentless crafting of an elastic self is required for both those who remain in management positions in education and those who seek them.

Keywords: new managerialism, gender practices, identities, power, education

\section{Introduction}

$\mathrm{T}_{\mathrm{v}}^{\mathrm{r}}$ he evolution of new forms of management in the public service sector is well documented (Davies et al., 2006; Farrell and Morris, 2003). The language of the market pervades the analyses and subsequent funding of public services including education (Ball, 2001). Ireland has also endorsed neoliberal capitalism (Allen, 2007) and the accompanying values of efficiency, competition, performativity and a culture of surveillance in the public sector (Lynch, 2006; Sugrue, 2004). In this article we consider the impact of new managerial reforms on the recruitment and retention of women in senior management posts across primary, secondary and tertiary education in Ireland. While teaching is a feminized profession, senior management appointments in education are disproportionately male (Brooking, 2004; Blackmore and Sachs, 2007; Moreau et al., 2008). A review of trends in Irish education (Grummell

Address for correspondence: *School of Education, UCD, Dublin; e-mail: dympna.devine@ucd.ie 
et al., 2009a) shows a pattern of decline in the numbers of women in senior management positions as one moves from lower paid posts in primary level to higher paid posts in the university sector. The last ten years have seen enormous changes in the management and control of Irish educational institutions deriving from an increased formalization through legislation, and devolving powers of governance to schools and universities. The Irish government has promoted an increasingly market-driven model of efficiency and accountability in its educational policies (Grummell et al., 2009a; Sugrue, 2004). This is particularly evident at higher education level where the OECD (2004, p. 8) notes the hegemonic consensus to the social and economic role of higher education from educational leaders and government alike. This accord is less apparent at primary and secondary sectors, ${ }^{1}$ in part due to the influence of a highly organized trade union movement and a strong tradition of partnership between teacher unions, managerial bodies, parents and the Department of Education and Science.

Drawing on data from a study of senior management education appointments in eight primary schools, eight secondary schools and seven higher education organizations, we show that a culture of new managerialism increasingly pervades Irish education. Following an outline of our theoretical perspective and the methodology employed for the study, we highlight how the culture of new managerialism leads to the crafting of an elastic self among senior managers in Irish education. This requires a relentless pursuit of working goals without boundaries in time, space energy or emotion. We explore how the experience of this elasticity is gendered, deriving from the moral imperative of women to be primary carers, as well as the need for both men and women to manage 'otherness' and 'do' or 'undo' their gendered identities in line with organizational cultural norms.

\section{Organizing identitities in new managerial times}

There is a cultural shift in educational organizations internationally, most especially in English-speaking countries, toward the values and orientations of the market (Davies et al., 2006; Farrell and Morris, 2003). As key negotiators of organizational culture, senior managers are impelled to negotiate their identities in the context of such change, engaging in a modality of control that includes 'managing the insides' (Alvesson and Willmott, 2002, p. 3). Flexibility, adaptability, self-empowerment and self-actualization are incorporated into the new worker identity (Halford and Leonard, 2001). The experience of management in this changing context can be a double-edged sword. On the one hand, there is a seductive aspect to management as a site for identity investment through the promise of power, status and purposeful action (Whitehead, 2001). On the other hand, deep insecurities arise deriving from demands for increasing surveillance, performance and accountability 
(Collinson, 2003; Linstead and Thomas, 2002). Foucault's $(1979,1980)$ analyses draw attention to the microphysics of power as central to processes of identity formation and the ways in which identities are fashioned in line with 'regimes of truth' that signify, classify and govern. In this sense, new managerialism exemplifies a regime of truth, 'bio-power' in action, increasing and promoting the body's utility, while at the same time rendering it dependent on external control and monitoring. Absent, however, from Foucault's analyses is a full acknowledgement of the complex interplay of agency and resistance to processes of identity formation (Clegg, 2006; McNay, 1992). Identities are something we do, not just something we are (West and Zimmerman, 1987); a form of situated social practice within which individuals perform roles that are relational and embedded in norms and expectations related to self and 'other' (Butler, 2004; McNay, 1999; Poggio, 2006; Pullen and Simpson, 2009). Conflicts and contradictions abound, multiple identities merge and overlap giving rise to a crafted self (Kondo, 1990) that is at once fragile and versatile, depending on the context of interaction and the resources individuals bring to it (Bourdieu, 1990; Devine, 2009).

The agency inherent in such positioning should not. however, mask the ambiguity and messiness that characterizes much of our identity positioning (Martin, 2006; Pullen and Knights, 2007; Pullen and Simpson, 2009). Part of this messiness derives from the ethical tensions that arise in the 'doing' of self in increasingly market-driven new managerial contexts. Rose (2001) notes the emphasis on self-realization and enterprise in the new managerialist paradigm - a governing of the soul that reflects the intensification of liberal subjectivities (Davies et al., 2006). Individualization is at the core of such processes - the liberal subject is free to chose, to commit to the organization as a matter of character, in effect to become a corporate citizen (Blackmore and Sachs, 2003). Such processes of identification involve a complex interplay between often competing demands and values as individuals struggle to retain personal meaning and connectedness in the face of colonization of the life-world in performative regimes (Habermas, 1987, p. 173). Such conflicts are especially pronounced in the caring professions, where the ethic of care and commitment to service is at the heart of professional practice. Market-oriented forms of new managerialism pose specific challenges in the health and education sectors because care itself is neither a quantifiable commodity nor an outcome that is open to strategic measurement. Within an increasingly managerialist system, educationalists struggle to retain a balance between their commitment to the broader goals of education (a careful education), with the more narrowly defined goals of performativity and competition (care-less in terms of a focus on narrowly defined outputs) in the education marketplace (Ball, 2003; Day et al., 2006; Lynch et al., 2007).

Research, however, draws distinctions in the experiences of identity construction and management across different sectors of education (Day, 2005), 
with some evidence of school principals successfully negotiating demands for performativity without compromising their core values in education. In contrast, research in the higher education sector highlights the prevalence of the audit culture and the construction of the manager academic, driven by publishing and research funding norms (Deem, 2003; Fletcher et al., 2007). Regardless of which sector is involved, what appears to be required is the exercise of a form of super-leadership (Caldwell and Spinks, 1992; Gunter, 2001) that requires the continual extension of self. While previous research defines the dilemma for educators in terms of a struggle between a plastic and an authentic self (Ball, 2001) we suggest that senior management in education requires the crafting of an elastic self that is continuously stretched by the intensity of demands within the management role. This is not, however, a gender-neutral process. We argue that elasticity is gendered and is more bounded for male than for female managers.

\section{Gender and the elastic self in senior management}

While it would be simplistic to assume a unidimensional analyses of gender identities (Knights and Kerfoot, 2004; Poggio, 2006), nonetheless the relentless extension of self that is required in greedy organizations characterized by new managerial reform (Currie et al., 2000) creates severe challenges for those who have primary care responsibilities outside work (Probert, 2005; Russell et al., 2009). Given the predominance of women in caring (Pettinger et al., 2006) and the moral imperative on women to do care work (O'Brien, 2007), it would appear that women face unique challenges combining their paid work and personal lives (Guillaume and Pochic, 2009; Lynch et al., 2009). For those working in the education sector, the emotional investment of self that is required to balance care and performance in school or college is exacerbated by the demands of primary caring outside of employment (Coleman, 2001; Moreau et al., 2008). Not surprisingly, women who do enter senior management often forfeit having children or take longer than their male counterparts to achieve promotion (Acker and Dillabough, 2007; Blackmore and Sachs, 2007).

To say that care work is highly gendered, both in and outside organizations, is not to suggest that caring poses dilemmas only for women. Men who are managers and who are primary carers can also experience conflicts over care in greedy work organizations (Grummell et al., 2009b; Hanlon, 2009). However, given that most men only do unpaid care work in households when there is no woman available or qualified to do it (Coltrane and Galt, 2000), and that men tend to enter care-related occupations such as social work and teaching by finding and settling in to them, rather than seeking them (Simpson, 2004), men remain disproportionately absent from caring work across many different levels of society (Cross and Bagilhole, 2002; Lupton, 
2006; Lynch et al., 2009). Masculinity is not equated with caring in the way that femininity is, so men can practice care-less masculinity without moral disapproval in a way women cannot practice femininity in a care-less manner (Hanlon and Lynch in press; Seidler, 2007).

Furthermore, an additional stretching is also required of women who enter managerial positions in organizations where men traditionally manage and which are characterized by a masculinized organizational culture (Knights and Kerfoot, 2004). They are the organizational 'other' and must manage their otherness or not succeed (Halford and Leonard, 2001; Probert, 2005). They have to minimize their gender difference in order to be treated equally to men, while at the same time retaining a distinct feminine identity so as not to be ridiculed for appearing overly masculine (Bailyn, 2003; Halford and Leonard, 2001). New managerialism has been posited as opening up opportunities for women through a de-layering of management structures, coupled with an increasing sensitivity to the importance of the emotions in managerial styles (Halford and Leonard, 2001). It has been suggested, however, that this new emancipatory framework, while valorizing qualities that have traditionally been marginalized (such as service, nurturance and empathy) merely harnesses the feminine in the pursuit of performativity (Knights and Kerfoot, 2004; Walkerdine et al., 2002), doing little to challenge the hyper-masculinist model of management that can prevail (Hatcher, 2003). As Walkerdine et al. note (2002, p. 2) it is easier to be 'one of the girls' than 'one of the boys' and women who enter management have to practice gender in a managed way to retain their status as women and as managers (Martin, 2006).

While men must also manage their identities in new managerial regimes (Knights and Kerfoot, 2004; Linstead and Thomas, 2002) and the management of masculine identities incorporates resistance as well as accommodation to dominant masculinist norms (Pullen and Simpson, 2009), elasticity is not quite the same for men as it is for women. For women in highly performative work environments, being elastic not only involves meeting the requirements of organizational productivity (and as with men) the fashioning of self as the $24 / 7$ worker but also extends to doing caring work both within and without the organization in feminine-defined ways. While men in education have to practice care in the organization, especially in primary schools, given the very explicit caring function of the latter, they are increasingly absolved from this role as they move from secondary to higher education.

\section{The study in context}

Mirroring patterns identified elsewhere, the percentage of women in senior management positions in Ireland declines as one moves from primary to higher education (Lynch et al., 2006). Half of all primary schools heads and a quarter of secondary heads of schools are women, none of the heads of 
Table 1: Gender and institutional profile of senior managers (assessor) interviewees

\begin{tabular}{|llllllll|}
\hline & \multicolumn{2}{c}{ Primary } & \multicolumn{2}{l}{ Secondary } & \multicolumn{2}{l}{ Tertiary } & Total \\
\hline Men & 4 & $(5)$ & 4 & $(6)$ & 3 & $(4)$ & 26 \\
Women & 4 & $(3)$ & 4 & $(2)$ & 4 & $(2)$ & 19 \\
Total & 8 & $(8)$ & 8 & $(8)$ & 7 & $(6)$ & 45 \\
\hline
\end{tabular}

the seven universities are women and only three of the 15 heads of institutes of technology are women. This research is based on an analysis of the appointments process for 23 senior managers across primary, secondary and higher education sectors. It sought to identify the cultural codes enshrined in both the process and experience of appointment, as well as the appointees' experience in post. A strategic sample was taken from national data of appointments provided by the Department of Education and Science to ensure representation across sectors. Each case consisted of an in-depth qualitative interview with the recently appointed educational manager (the school principal or head teacher in the case of primary and secondary schools and at the level of president, director, vice-president or dean in higher education institutions) and an interview with one or more assessors from the interview board, each of whom had considerable experience of management in the education system, as well as documentary analysis of advertisements and policies governing appointments ( 45 interviews in total, see Table 1). The three sectors of Irish education were represented in these 23 cases, including eight primary and eight secondary schools (co-ed and single sex across a variety of urban and rural geographical areas, socioeconomic backgrounds and school sizes), and seven higher education institutions (universities, institutes of technology, further education colleges and a statutory educational agency). An equal gender balance of candidates was achieved with the exception of higher education, where three male and four female appointees were interviewed. A qualitative software package, MAXqda was used because it facilitates systematic organization and coding of both interview and documentary data. Open coding was used to identify the initial findings, with theoretical reflection in line with the literature analysing the significance of these findings in greater depth. Pseudonyms are used throughout.

The remainder of the article considers the findings of the study with respect to two interrelated themes. Firstly, it explores the relentless extension of the self that is required in working as a senior manager in the education sector and secondly it considers how the experience of this stretching is gendered. 


\section{Crafting the elastic self? Senior management in an era of educational change}

Senior appointees spoke at length about their experiences in their new posts, providing a detailed overview of the work of educational leaders in the Irish education system. They outlined systems of accountability and performativity underpinned by extensive legislative and policy change:

There's the Welfare Act, the Education Act itself. Special Needs now is the other big one that people are talking about: the pile of stuff has gone bigger. (Tom, principal, Secondary Scoil Nephin)

The new requirements under the 1997 Act ... delineate a form of management that is alien, if you like, to the traditional notion of a university. (Aisling, assessor, InisMhean Higher Education Institution)

Change was experienced differently across the educational sectors, however, most notably between the school sectors and the higher education and statutory sectors. For those in the school sector the new managerial culture was experienced primarily through the intensification of bureaucratic demands, ${ }^{2}$ often without the appropriate administrative back up to support the change:

So, you have the new curriculum, you've got legislation, you've got special needs, you've got health and safety ... and the one person that it impacts upon by increasing the workload is the principal. (Deirdre, assessor, Primary Level Scoil Derg)

Such control extended beyond the school day as principals struggled to cope with the myriad demands placed upon them. Most school principals worked very long days and those who did not stay on late after school tended to do their administrative work late in the evenings at home or at the weekend. Niamh, the principal of a secondary school, described 'time commitment and responsibility' as one of the biggest personal challenges that faced senior managers in schools. Her views were shared by others:

The Department of Education and Science are so overburdening us with reports, with compliance, that the principal doesn't get a chance to have time to nurture their own sense of what the school should be about. (David, assessor, Secondary Scoil Sperrin)

This pressured work context gave rise to ethical dilemmas that were bound to the appointees' desire to retain personal meaning and connectedness beyond the system-led regulations of bureaucratic change. Emotions of guilt and depression, feeling overburdened and swamped sat alongside the energy and buzz these senior appointees experienced in their roles as they managed their insides (Alvesson and Willmott, 2002): 
It is tiring and it is wearing ... but you get on with it. (Patricia, principal, Secondary Scoil Mourne)

The guilt I had as a teaching principal ${ }^{3}$ [was] because you were always being distracted ... the guilt now is that I'm not doing my job well enough as a principal. (Eoghan, principal, Primary Scoil Corrib)

Gunter (2001) speaks of the super leadership that is required of leaders in education, continuously stretching themselves with an intense commitment to the pursuit of educational goals. It was this passion (Hatcher, 2003) and commitment to care for the community in which their schools were based that drove these principals, in spite of their struggles with the multifaceted demands that mangerialism placed upon them:

My philosophy starts with the child in the classroom and it ends with the child in the classroom. I aspire to provide the best possible education for them. (Andrew, principal, Primary Scoil Derravaragh)

Recently appointed senior managers in the tertiary and statutory sector appeared less conflicted about their roles. Their decision to apply for these senior management positions almost reflected an internalization of managerialism into their constructs of manager identity. Managerialism was talked about as inevitable in an increasingly competitive national and international environment:

What I think we have needed is to create higher levels of strategic efficiency. We were a university system that developed on a totally opportunistic basis, and that, in international benchmarking terms, was not sustainable. (Brendan, assessor, InisMhean Higher Education Institution)

I don't feel I am terribly conflicted that there is any clash between that [the budgetary and managerial role] and people's academic integrity at all. (Una, senior appointee, Rathlin Higher Education Institution)

While interviewees in this sector were also concerned about issues related to student welfare, the tensions between a discourse of care versus that of managerialism was not as strong in their narratives. More prevalent were tensions in managing the time bind between their administrative responsibilities and the demand for publishing, research funding and developing a competitive edge in new fields. In this sense it was clear that the organizational culture within which they worked was one where performativity was more readily individualized to the person (Rose, 2001) underpinned by disciplinary technologies which laid out clear pathways of 'recognition':

With our research information system it is the people who are obviously deserving who are being recognized. And for the others there is a clear route 
to recognition. (Paul, senior appointee, InisMhean Higher Education Institution; emphasis added)

Coping with this changed culture gave rise to a time commitment to work which was experienced as being without boundaries. Self and work merged to the exclusion of outside activities, ensuring exclusive commitment to corporate and manager identity (Blackmore and Sachs, 2003):

I'd say on average I work an 85 hour week ... most of us at the level I am at, it's just work, there is nothing else in our lives. (Aisling, assessor, Inismhean Higher Education Institution)

In the depths of winter when we are working days and nights I can become an incredibly dull person ... work in a management post takes up a lot of time. (Neasa, senior appointee, Saltees Higher Education Institution)

Across all sectors it was clear that senior management was classified as an all-consuming activity, underpinned by an individualistic discourse that placed the burden of impact and change on the shoulders of each of the senior managers. In spite of the differences across the sectors in terms of how new managerialism is being implemented, however, the intensity of reforms appears to require a project of self-realization in which commitment to the organization is paramount.

Given that there are gender differences in patterns of recruitment and retention in senior management across the education sectors, it is appropriate to consider next how the experience of elasticity in management is gendered, firstly in terms of struggles to maintain a balance between home and working life and secondly, by the need to do and undo gender identities in line with organizational norms.

\section{Gender, care and the elastic self in senior management}

Each of the women interviewed had reached senior management level, yet clear differences emerged between interviews with them and those of their equally successful male colleagues with respect to the impact of gender on their decision to become senior managers. All female interviewees made reference to the significance of caring work and the raising of children as a key factor mediating women's experience of career progression, while no male interviewee mentioned it as a significant factor for men as a group. That women were the primary carers of children was a core assumption of a number of assessors and school principals, both male and female:

Why would any sane woman in her thirties or forties with a happy family life abandon it to go into the trenches of administration and management? (John, assessor, Secondary Scoil Galtees) 
[My friend] was a principal and told me I was mad and 'what on earth did I want to do principalship for' and 'don't you have a young child?' (Sarah, principal, Primary Level Scoil Sheelin)

A discourse of individualization permeated interviewees' accounts in that it was assumed that the decision to opt into or out of senior management was a lifestyle, and indeed moral, choice that derived from women's 'natural' role as mothers and carers. Indicative of the unreflexive practising of gender (Martin, 2006) that essentializes the characteristics of women (and men), it was not seen as a prescribed gendered choice arising from the way the senior management role was itself constructed:

Women are at a later state in their careers [when they apply for promotion] generally, and that is their decision and that probably makes sense to them and probably it is sensible. (Patrick, assessor, Primary Level Scoil Allen; emphasis added)

I think a lot of women are determining their work-life balance and particularly their child-rearing responsibilities would be absolutely constrained by being appointed to a more senior post. (Carol, assessor, Valentia Higher Education Institution)

The construction of the senior management role as relentless ensured particular, and often insurmountable, challenges for women positioned as primary carers, and considerable stretching in order to manage both:

The last couple of nights [for example] I've brought work home with me and when the kids are gone to bed I can work on some of the paper work ... and I might come in on a Saturday or Sunday. (Anne, principal, Secondary Scoil Neagh)

The difficulty of combining childcare with intensified senior management responsibilities was alluded to across all sectors. It was defined as least problematic in the primary school sector and to a slightly greater degree in the secondary sector, provided women had the appropriate support services in place:

There are loads of women who have children and who are principals and it works out fine ... you need to have a very good back-up system. (Meabh, principal, Secondary Scoil Comeragh)

New managerialism appeared to have a more explicit impact on both the life choices and life chances of women in the higher education sector, given the level of overt performativity that was embedded in the senior management role. Furthermore, the moral imperative on women to practice gender as caring (O'Brien, 2007; Poggio, 2006) meant that some were deprived of important management experience when applying for top-level positions: 
At the most likely time in your career where you are going to get this management experience, many women have taken time out to rear kids or maybe are rearing kids and are working and are not going to put themselves forward to take on extra loads. (Gráinne, assessor at Tory Higher Education Institution)

The higher you go, the reality is that the options are much starker. If you take jobs at my level, you are lucky to only get a 5-day week. (Mathew, assessor, Saltees Higher Education Institution)

There was a belief that total dedication to the job was essential at senior levels and that this may preclude women from taking such positions. This was made clear to a female applicant to a senior post by an interviewee who sat on many selection boards and who was himself in a senior position:

The candidate we chose said that she wouldn't be able to devote her time to all the teaching and research as I wanted, so in the end she chose not to join the Department. (Paul, senior appointee, InisMhean Higher Education Institution; emphasis added).

Men in the study also spoke of the time bind (Hochschild, 1989) and intense commitment of their management roles, but issues around childcare were not part of their mind maps in the way they were for women interviewees. There were men in the study with young children, yet it was clear they were generally positioned as secondary carers, and being a father was not presented as a moral dilemma for them in deciding to apply for a senior management position or in negotiating their management role. Differences were also identified, however, in the 'otherness' interviewees experienced by virtue of their gender that was influenced by the organizational culture in which they worked. This resulted in additional stretching in carrying out management functions as they learned to do gender in line with dominant organizational norms.

\section{Managing otherness across the educational sectors - the doing and undoing of gender identities}

Senior managers strategically managed their gender identities in line with the dominant gendered organizational cultures in their sectors. In the primary sector, especially, there was evidence that male principals, positioned as 'other,' managed their maleness (Linstead and Thomas, 2002) in order to accommodate to the more feminized cultures of primary school staff (Drudy et al., 2005). This is apparent not only in assumptions regarding the more feminized nature of men who enter primary teaching (Pullen and Simpson, 2009), but also in the comment of Eoghan, a recently appointed principal, when he spoke of having to readjust his strong management style: 
I would have come away with the impression that because it [staff] was so heavily female that a strong male may have presented a threat. I might be paranoid: it's a perception. (Principal, Primary Level Scoil Corrib)

I think men in education generally tend to be more - they tend to be more in touch with their female side, you know, because they're in a caring profession. (Meabh, principal, Primary Level, Scoil Comeragh)

In contrast a more competitive masculinist culture is reflected in higher education not only in the significantly greater representation of men in management positions, but also in management styles that were spoken of as being tough and competitive:

The institution was remarkably male dominated, the senior management team, all seven of those were male. (Donal, senior appointee, Inisbofin Higher Education Institution)

I would have many, many experiences of men taking on each other and it being a fight to the end ... I don't think women have the same fighting instinct. (Aisling, assessor InisMhean Higher Education)

Just as Eoghan in Scoil Corrib felt he had to undo his maleness in line with more feminized norms of identity performance, the corollary applied in the doing of maleness in higher education institutions, where the more hierarchical and compulsive culture (Knights and Kerfoot, 2004) is presented as a challenge for Andrew:

I think the first time around I was the little guy, so we [in our centre] were not getting proper recognition for what we were doing. Once I became [senior position] then I was visible. (Andrew, senior post holder Coláiste InisMhean)

Women who chose to move into senior management in such sectors also strategically managed their otherness. This involved masking their femaleness (Linstead and Thomas, 2002) through a strategic distancing from what was perceived as low-status caring work (Blackmore and Sachs, 2007) and the adoption of the stereotypical nurturing, motherly role:

People have expectations for women in power that they would never have of men ... I have to be careful I don't do all the 'busy' work. (Nuala, senior appointee, Valentia Higher Education Institution)

You can still find this kind of slightly, not exactly secretarial but that kind of a role somehow can fall to you if you are not careful. And, frankly, if you refuse it you are often perceived as being difficult. But that is a minefield 
that still is there for [women]. (Una, senior appointee, Rathlin Higher Education Institution)

I don't go for the deferential, 'yes, Minister' kind of approach. I am a very political animal: you have to be to operate in this arena. (Sarah, senior appointee, Saltees Higher Education Institution)

Such struggles are also reflected in the tension female interviewees spoke of in managing the binary of mother and career. This is acutely evident in Una's accounts of crafting her identity in line with managerial norms. Reflecting technologies of the self that are ingrained in the body at the deepest level in the regulation of her fertility — she 'chooses' to regulate her family size:

I made a conscious decision that I couldn't have a second child. And perhaps there is some naivety about the impact having children has on their [female colleagues] careers and where it keeps them. (Una, senior appointee, Rathlin Higher Education Institution).

In this way, Una undoes the prescribed gender role of mother in light of the negative impact this could have on her career (Wood and Newton, 2006). Simultaneously, however, her very resistance ensures compliance (Fleming and Sewell, 2002) to dominant expectations related to care-lessness and career progression. Her strategy of undoing gender norms reinforces the organizational status quo (Pullen and Simpson, 2009) of the construction of the senior manager as a zero load worker, devoid of familial and care responsibilities (Grummell et al., 2009b).

Embodied self-regulation, in particular the 'looked-at-ness' of the feminine (Walkerdine et al., 2002), is reflected in the comment of Nuala regarding the difficulty for younger women especially in being taken seriously in management roles:

One of the benefits of being older and greyer is that you do get taken more seriously [as a woman] than when you are younger and slimmer. You are either attractive or serious ... sadly, that is my experience. (Nuala, senior appointee, Valentia Higher Education Institution)

For senior women, doing gender also involved coping with feelings of isolation or loneliness on a male-dominated senior management team. Their resistance to being stereotyped as soft and caring and the accompanying need to be tough carried with it the threat of exclusion from female peers who were not part of the management team. Managing this double binary in terms of their relations with female peers was an additional challenge, carrying with it ambiguities of what being a female, boss, manager and friend meant. This, it was felt, acted as a potential deterrent to women to go for promotion: 
Women are very afraid that if they take on a senior role that they will somehow lose their feminine qualifications as a female ... a lot of females have that 'if I become the boss I won't be attractive, I won't be a good girlfriend, other women won't like me, senior women can be so mean'.... So I think there is a bit of an identity thing for women. (Una, senior appointee, Rathlin Higher Education Instutition)

You get very tough in the game and I know from talking to my female colleagues they are quite determined they are not going there. I read Machiavelli's Prince and I'm utterly convinced by what it says. (Aisling, female assessor, InisMhean Higher Education)

Neasa counteracted this relative isolation by strategically seeking out networks where other senior women met:

I joined the ... association and that brought me into contact with other women who were in senior management posts and they were fantastic. (Senior appointee, Saltees Higher Education Institution)

However, while these female senior appointees were aware of their 'otherness' within the male emporium (Acker and Dillabough, 2007) of higher education, this did not imply that they felt they were discriminated against, overtly at any rate. Their responses to any experiences of sexism were in the main ambivalent and individualized as a form of paternalistic masculinity:

Some older male comments have been a sort of humane sexism that is sort of understandable. (Neasa senior appointee, Saltees Higher Education Institution)

I felt under serious pressure from the maternity leave. I didn't feel I could tell them that I was breastfeeding ... this wasn't bias or anything, they must have thought that they had got a mad woman ... I mean I totally understand. (Nuala, senior appointee, Valentia Higher Education Institution)

The psychological interiority (Poggio, 2006) evident in the comment by Nuala (where she internalizes her 'otherness' as a matter of personal circumstance) highlights the messiness of the identity project (Poggio, 2006; Pullen and Knights, 2007) and the feelings of ambiguity that can underpin these women's orientation toward their gender performance at work. It is reiterated by Una when she claims that it was her own lack of savvyness that precluded her from obtaining a professorship at the same time as some of her male colleagues:

I did feel uncomfortable when I realized that I was the only female senior appointee [at this level] who wasn't professor ... had I been more savvy I should have asked for it. (Una, senior appointee, Rathlin Higher Education Institution) 
However, this is where the issue of how the management role is constructed becomes crucially important, especially with respect to the attractiveness of management positions for those who do not conform to the dominant gendered organizational cultural norms. The claim that new managerialism represents a meritocratic ideal, allowing those with the greatest drive and entrepreneurialism to rise to the top is seriously questionable. It does not acknowledge the structural conditions that govern the choice people make, especially those relating to gender:

In universities the fact that most promotion now prioritizes research means that it is very difficult for women to devote the amount of time that seems to be necessitated by producing research and publications. (Nuala, senior appointee, Valentia Higher Education Institution).

Some progress has been made in primary and secondary level schools by encouraging women to apply and having networks of women and so on. But it hasn't come to that yet in the university sector. (Aisling, assessor, InisMhean Higher Education Institution)

\section{Concluding discussion}

New managerialism has profound implications for the construction and experience of management in education organizations. Underpinned by the neoliberal logic of the rational and voluntary choosing subject, senior managers are stretched personally and professionally, super-leaders (Gunter, 2001) maximizing the investment of their selves in their working lives. Differences are evident across the education sectors, however, in how elasticity works and how gendered it is in its operation. While the more overt neoliberal focus on school performance evident elsewhere has been to some extent resisted in the school sector in Ireland, the management role still requires intense commitment to the school and its local community. In higher education a more pronounced emphasis on performative identities was evident. Effective senior management required relentless commitment to the strategic goals of the organization and an implicit assumption of their $24 / 7$ availability to their management roles.

Cutting across this experience of management was gender, most specifically in terms of the management of caring relations (both inside and outside work), as well as in the performance of gendered identities. In doing management, senior appointees had to both do and undo their gender identities, depending on organizational norms. With respect to women interviewees, the endlessness that is core to women's caring work (Acker and Dillabough, 2007), coupled with the relentlessness of new managerial demands ensured a degree of self-regulation (in terms of fertility and taking time out of paid work) and stretching of self that was generally not evident among male 
interviewees. While more masculinized organizational cultures were evident as one moved up through the education sectors, even in the more feminized primary school sector, it was assumed that women's role as primary carers in the home precluded many from applying for senior management positions in education.

Not only does this highlight assumptions around the construction of the idealized manager as one unencumbered by care responsibilities, it also locates women as free choosing subjects, the bearers of responsibility for their own lack of career progression. This myth of choice is itself problematic, as it allows public organizations to be seen as gender-neutral, which they are not (Connell, 2006). While there were men in the research who also had care responsibilities, their role as secondary carers ensured that they did not have to engage in the same degree of emotional work in managing the time bind (Hochschild, 1989) between work and home. Additional gender work was also required of female senior managers in organizations where men predominated, masking the feminine (Linstead and Thomas, 2002; Knights and Kerfoot, 2004) with more overtly masculinist ways of being and doing. While men also struggled for recognition in masculinist organizational cultures (Martin, 2006), only one male interviewee, a principal of a primary school with an all-female staff, identified his maleness in problematic terms. While there can be ambiguities and messiness in the doing of gender for both men and women (Pullen and Knights, 2007), practising gender at work operates in the context of the masculinization of management (Linstead and Thomas, 2002). Such patterns, it is argued, are becoming more, rather than less embedded under new managerial reforms.

These findings are important in a number of respects. Firstly, the construction of senior management positions as involving the unlimited resources of time and energy serves to exclude those who aspire to integrate their professional and personal lives in a balanced manner. While this may apply strongly to only women now, it has implications for men who are primary carers now and in the future. Secondly, in spite of the raft of legislative and policy provisions to promote gender equality, the findings suggest that the ideology of choice conceals the ways in which organizations structurally exclude those who are not care-free. While this can apply to both men and women, the experience of 'otherness' that was alluded to by women in the tertiary sector, and which has been documented in other studies (Bailyn, 2003; Benschop and Brouns, 2003; Probert, 2005) suggests that it is primarily a problem for women. Of particular concern is the individualization of gendered experiences in the talk of both senior appointees and assessors across the 23 organizations and the assumption that self-selection out of management positions was not a matter of institutional but individual concern and responsibility. Adherence to strict legislative criteria for gender equality can mask the more subtle forms of exclusion that institutional, and especially managerial, cultures can take. 


\section{Notes}

1. This is evident in the relatively successful resistance of the teacher unions to the publication of school league tables, as well as an underpinning of a partnership approach in the Education Act 1998.

2. This included, for example, endless form-filling, applications for grants and funding and school development planning.

3. In small primary schools the head teacher or principal also teaches a class.

\section{References}

Acker, S. and Dillabough, J. (2007) Women 'learning to labour' in the 'male emporium': exploring gendered work in teacher education. Gender and Education, 19,3, 297-316.

Allen, K. (2007) The Corporate Takeover of Ireland. Dublin: Irish Academic Press.

Alvesson, M. and Willmott, H. (2002) Identity regulation as organizational controlproducing the appropriate individual. Journal of Management Studies, 39,5, 619-44.

Bailyn, L. (2003) Academic careers and gender equity: lessons learned from MIT. Gender Work \& Organization, 10,2, 137-53.

Ball, S.J. (2001) Performativities and fabrications in education and economy: towards the performative society. In Gleeson, D. and Husbands, C. (eds) The Performing School, pp. 210-26. London: Routledge Falmer.

Ball, S.J. (2003) The teacher's soul and the terrors of performativity. Journal of Education Policy, 18,2, 215-28.

Benschop, Y. and Brouns, M. (2003) Crumbling ivory towers: academic organizing and its gender effects. Gender, Work \& Organization, 10,2, 194-212.

Blackmore, J. and Sachs, J. (2003) Zealotry or nostalgic regret? Women leaders in technical and further education in Australia: agents of change, entrepreneurial educators or corporate citizens? Gender, Work \& Organization, 10,4, 478-503.

Blackmore, J. and Sachs, J. (2007) Performing and Reforming Leaders: Gender, Educational Restructuring and Organizational Change. New York: State of New York Press.

Bourdieu, P. (1990) The Logic of Practice. Cambridge: Polity.

Brooking, K. (2004) Board of Trustees selection practices of primary school principals in New Zealand. New Zealand Journal of Teachers' Work, 1,1, 27-31.

Butler, J. (2004) Undoing Gender. London: Routledge.

Caldwell, B. and Spinks, J. (1992) Leading the Self-managing School. London: Falmer.

Clegg, S. (2006) The problem of agency in feminism: a critical realist approach. Gender and Education, 18,3, 309-24.

Coleman, M. (2001) Achievement against the odds: the female second-level headteachers in England and Wales. School Leadership and Management, 21,1, 75-100.

Collinson, D.L. (2003) Identities and insecurities: selves at work. Organization, 10,3, 527-47.

Coltrane, S. and Galt, J. (2000) The history of men's caring. In Meyer, M.H. (ed.) Care Work: Gender, Class and the Welfare State, pp. 15-36. New York and London: Routledge.

Connell, R. (2006) The experience of gender change in public sector organizations. Gender, Work \& Organization, 13,5, 435-52.

Cross, S. and Bagilhole, B. (2002) Girls' jobs for the boys? Men, masculinity and nontraditional occupations. Gender, Work \& Organization, 9,2, 204-26.

Currie, J., Harris, P. and Thiele, B. (2000) Sacrifices in greedy universities: are they gendered? Gender and Education, 12,3, 269-91. 
Davies, B., Gottsche, M. and Bansel, P. (2006) The rise and fall of the neoliberal university. European Journal of Education, 41,2, 305-19.

Day, C. (2005) Principals who sustain success: making a difference in schools in challenging circumstances. International Journal of Leadership in Education, 8,3, 27390 .

Day, C.K., Stobart, G. and Sammons, P. (2006) The personal and professional selves of teachers: stable and unstable identities. British Educational Research Journal, 32,4, 601-16.

Deem, R. (2003) Gender, organizational cultures and the practices of manager academics in UK universities. Gender, Work \& Organization, 10,2, 239-59.

Devine, D. (2009) Migrant children's negotiation of their everyday lives in school. British Journal of Sociology of Education, 30,5, 521-35.

Drudy, S., Martin, M., Woods, M. and O'Flynn, J. (2005) Men and the Classroom: Gender Imbalances in Teaching. London: Routledge.

Farrell, C.M. and Morris, J. (2003) The 'neo-bureaucratic' state: professionals, managers and professional managers in schools, general practices and social work. Organization, 10,1, 129-46.

Fleming, P. and Sewell, G. (2002) Looking for the good soldier, Švejk: alternative modalities of resistance in the contemporary workplace. Sociology, 36,4, 857-73.

Fletcher, C., Boden, R., Kent, J. and Tinson, J. (2007) Performing women: the gendered dimensions of the UK new research economy. Gender, Work \& Organization, 14,5, 433-53.

Foucault, M. (1979) Discipline and Punish: the Birth of the Prison. New York: Vintage Books.

Foucault, M. (1980) Michel Foucault: Power Knowledge. Hemmel Hempstead: Harvester Wheatsheaf.

Grummell, B., Devine, D. and Lynch, K. (2009a) Appointing senior managers in education: homosociability, local logics and authenticity in the selection process, Educational Management Administration and Leadership, 37,3, 329-49.

Grummell, B., Devine, D. and Lynch, K. (2009b) 'The careless manager: gender, care and new managerialism in higher education. Gender and Education, 21,2, 191-208.

Guillaume, C. and Pochic, S. (2009) What would you sacrifice? Access to top management and the work-life balance. Gender, Work \& Organization, 16,1, 14-36.

Gunter, H. (2001) Leaders and Leadership in Education. London: Paul Chapman

Habermas, J. (1987) The Theory of Communicative Action. Vol 2: Lifeworld and System: A Critique of Functional Reason. Boston, MA: Beacon Press.

Halford, S. and Leonard, P. (2001) Gender, Power and Organizations. New York: Palgrave.

Hanlon, N.I. (2009) Caregiving masculinities: an exploratory analysis. In Lynch, K Baker, J. and Lyons, M. (eds) Affective Equality: Love Care and Injustice, pp. 180-98. Basingstoke: Palgrave Macmillan.

Hatcher, C. (2003) Refashioning a passionate manager: gender at work. Gender, Work \& Organization, 10,4, 391-411.

Hochschild, A. (1989) The Second Shift: Working Parents and the Revolution at Home. Harmondsworth: Penguin.

Knights, D. and Kerfoot, D. (2004) Between representations and subjectivity: gender binaries and the politics of organizational transformation. Gender, Work E Organization, 11,4, 430-54.

Kondo, D. (1990) Crafting Selves: Power, Gender and Discourse of Identity in a Japanese Workplace. Chicago, IL: University of Chicago Press.

Linstead, A. and Thomas, R.T. (2002) 'What do you want from me?' A poststructuralist feminist reading of middle managers' identities. Culture and Organization, 8,1, 1-20. 
Lupton, B. (2006) Explaining men's entry into female-concentrated occupations: issues of masculinity and social class. Gender, Work \& Organization, 13,2, 103-28.

Lynch, K. (2006) Neo-liberalism and marketization: the implications for higher education. European Educational Research Journal, 5,5, 1-17.

Lynch, K., Grummell, B., Devine, D. and Lyons, M. (2006) Senior Appointments in Education: a Study of Management Culture and its Gender Implications. Dublin: Gender Equality Unit, Department of Education and Science.

Lynch, K., Lyons, M. and Cantillon, S. (2007) Breaking the silence: educating for love, care and solidarity. International Studies in Sociology of Education, 17,12, 1-19.

McNay, L. (1992) Foucault and Feminism. Oxford: Polity Press.

Lynch, K., Baker, J. and Lyons, M. (2009) Affective Equality: Love, Care and Injustice. London: Palgrave Macmillan.

McNay, L. (1999) Subject, psyche and agency: the work of Judith Butler. Theory, Culture \& Society, 16,2, 175-93.

Martin, P.Y. (2006) Practising gender at work: further thoughts on reflexivity. Gender, Work \& Organization, 13,3, 254-76.

Moreau, M., Osgood, J. and Halsall, A. (2008) Equal opportunities policies in English schools: towards greater gender equality in the teaching workforce? Gender, Work $\mathcal{E}$ Organization, 15,6, 553-76.

O'Brien, M. (2007) Mothers' emotional care work in education and its moral imperative. Gender and Education, 19,2, 159-77.

OECD (2004) Review of National Policies for Education: Review of Higher Education in Ireland. Paris: OECD.

Pettinger, L., Parry, J., Taylor, R. and Gluckmann, M. (eds) (2006) A New Sociology of Work? Oxford: Basil Blackwell.

Poggio, B. (2006) Editorial: outline of a theory of gender practices. Gender, Work $\mathcal{E}$ Organization, 13,3, 225-32.

Probert, B. (2005) 'I just didn't fit in': gender and unequal outcomes in academic careers. Gender, Work \& Organization, 12,1, 50-72.

Pullen, A. and Knights, D. (2007) Editorial: undoing gender: organizing and disorganizing performance. Gender, Work \& Organization, 14,6, 504-11.

Pullen, A. and Simpson, R. (2009) Managing difference in feminized work: men, otherness and social practice. Human Relations, 62,2, 561-87.

Rose, N. (2001) Governing the Soul. Cambridge: Cambridge University Press.

Russell, H., O'Connell, P. and McGinty, F. (2009) The impact of flexible working arrangements on work-life conflict and work pressure in Ireland. Gender, Work $\mathcal{E}$ Organization, 16,6, 73-97.

Seidler, V. (2007) Masculinities, bodies, and emotional life. Men and Masculinities, 10,1, 9-21.

Simpson, R. (2004) Masculinity at work: the experience of men in female-dominated occupations. Work, Employment \& Society, 18,2, 349-68.

Sugrue, C. (ed.) (2004) Curriculum and Ideology: Irish Experiences, International Perspectives. Dublin: Liffey Press.

Walkerdine V., Lucey H. and Melody, J. (2002) Growing Up Girl: Psycho-social Explorations of Class and Gender. London and New York: Palgrave and New York University Press.

West, C. and Zimmerman, D. (1987) Doing gender. Gender \& Society, 1,2, 125-51.

Whitehead, S. (2001) Woman as manager: a seductive ontology. Gender, Work \& Organization, 8,1, 84-107.

Wood, G.J. and Newton, J. (2006) Childlessness and women managers: 'choice', context and discourses. Gender, Work E Organization, 13,4, 338-58. 
Copyright of Gender, Work \& Organization is the property of Wiley-Blackwell and its content may not be copied or emailed to multiple sites or posted to a listserv without the copyright holder's express written permission. However, users may print, download, or email articles for individual use. 